University of Nebraska - Lincoln

DigitalCommons@University of Nebraska - Lincoln

Publications from USDA-ARS / UNL Faculty

U.S. Department of Agriculture: Agricultural

Research Service, Lincoln, Nebraska

2008

Codling Moth Areawide Integrated Pest Management

Alan L. Knight

USDA-ARS

Follow this and additional works at: https://digitalcommons.unl.edu/usdaarsfacpub

Part of the Agricultural Science Commons

Knight, Alan L., "Codling Moth Areawide Integrated Pest Management" (2008). Publications from USDAARS / UNL Faculty. 651.

https://digitalcommons.unl.edu/usdaarsfacpub/651

This Article is brought to you for free and open access by the U.S. Department of Agriculture: Agricultural Research Service, Lincoln, Nebraska at DigitalCommons@University of Nebraska - Lincoln. It has been accepted for inclusion in Publications from USDA-ARS / UNL Faculty by an authorized administrator of DigitalCommons@University of Nebraska - Lincoln. 


\title{
Codling Moth Areawide Integrated Pest Management
}

\author{
ALAN L. KNIGHT \\ Yakima Agricultural Research Laboratory, Agricultural Research Service, \\ Wapato, Washington, USA
}

\section{Introduction}

Codling moth (CM) is an insidious pest, tunnelling to the core of valuable commodities that are typically marketed with exceptional quality standards for appearance, firmness and sweetness. While there is no mention in the Bible of whether the apple that Eve gave to Adam graded 'Extra fancy', it is likely that if this fruit had been infested with CM, the human race would not be as anxious about returning to a pest-ridden garden of paradise. Nevertheless, since Noah allowed two adult CM to disembark from his boat, the distribution of this pest has closely followed man's cultivation of its hosts around the world (Shel'deshova, 1967). Historically, commercial plantings of both apple (Malus domestica Borkhausen) and pear (Pynus communis L.) have been heavily sprayed with seasonal programmes of broad-spectrum insecticides as part of the management of CM (Barnes, 1959; Madsen and Morgan, 1970). These intensive and indiscriminate management practices have not only defined the efficacy of control for this key pest, but also the population dynamics of a suite of secondary pests and their associated natural enemies, and the occurrence of several negative spill-over effects related to the environment and human safety (Prokopy and Croft, 1994).

Growers in the USA were offered in the early 1990s a new integrated pest management programme (IPM) for their orchards that hinged on the adoption of sex pheromones for mating disruption (MD) of CM, an intensive monitoring programme and the judicious use of more selective pesticides (Barnes et al., 1992). Initial testing of this integrated approach, when applied to individual small orchards with low CM pressure, was mostly successful (Howell and Britt, 1994; Knight, 1995a; Gut and Brunner, 1998). Yet, some growers experienced higher levels of CM damage. The cost of the new IPM programme was higher than most growers' current management programmes because many growers applied only a few seasonal sprays for CM, and subsequent reductions in the use of pesticides to manage secondary pests were minimal (Knight, 1995a; Williamson et al., 1996). Secondly, new pest problems 
developed in many orchards that required the application of additional sprays, further disrupting the implementation of IPM and raising the new programme's overall cost (Knight, 1995a; Gut and Brunner, 1998). Thirdly, the performance of the early dispensers was poor as the sex pheromones were not well protected and their emission rates were not adequate late in the season (Brown et al., 1992; Knight et al., 1995). Perhaps not surprisingly, a significant proportion of growers initially adopting the use of MD dropped out of the IPM programme prior to 1995 (Howell and Britt, 1994).

An areawide pest management (AWPM) approach was proposed as a potentially more effective strategy that could improve both the performance of sex pheromones and biological control (BC) (Kogan, 1995). AWPM accepts that pests and their natural enemies do not recognize individual orchards' boundaries and that effective management requires a coordinated, regionally focused project (Knipling, 1979). Essentially, the programme was conceived as a 'pyramid scheme', where more and more small growers situated in the centre of an ever-expanding project would benefit as all potential sources of CM impacting their orchards would be treated with MD and intensively monitored, and that the expanding area coming under a more selective management programme would harbour a significant increase in populations of natural enemies and their contribution to $\mathrm{BC}$ would also increase.

Demonstration of this concept was initiated in 1995 in a multi-institutional programme created by a close collaboration of university and governmental researchers in Washington, Oregon and California, with primary funding provided by the US Department of Agriculture's (USDA) Agricultural Research Service (ARS) (Kogan, 1994). The 5-year CAMP (CM Areawide Management Program) was the first of the areawide programmes initiated by USDA. The goal of this programme was to implement, assess, research and educate the industry about promising new IPM technologies. CAMP was highly successful in fuelling the rapid adoption of a new paradigm in orchard pest management that resulted in significant reductions in fruit injury using nearly $80 \%$ less broad-spectrum insecticides.

\section{Constraints in Developing Areawide CM Management}

Management of CM is difficult due to a number of operational, biological and ecological factors. CM is well adapted to the temperate climate zones, can have one to four generations per year and overwinters as a mature larva hibernating in protected bark crevices (Riedl and Croft, 1978). Both sexes are winged and they can disperse widely between managed and unmanaged hosts (White et al., 1973; Knight et al., 1995). Unmanaged sites can include backyard fruit trees, municipal plantings of crab apples, trees surviving at old homesteads and along pasture fencerows and in poorly managed orchards.

Female moths emerge with mature oocytes and have to mate only once to lay a full complement of fertile eggs (Howell, 1991). Females can deposit 50-100 eggs that are laid individually on or adjacent $(<15 \mathrm{~cm})$ to fruits (Jackson, 1979). This oviposition strategy minimizes predation and larval competition for fruits, while maximizing the proportion of fruits that are attacked. Levels of fruit injury can rise 
rapidly between generations, and unmanaged orchards can experience over $80 \%$ fruit injury (Myburgh, 1980). Neonate larvae do not generally feed before entering the fruit, which significantly reduces the effectiveness of many of the selective insecticides that require ingestion (Croft and Riedl, 1991). Larvae tunnel through the flesh of the fruits to feed on the seeds, rendering fruit infested by even a single larva worthless.

Natural control of CM due to predation or parasitism of eggs and larvae is low in unmanaged sites (Falcon and Huber, 1991) or in orchards under MD (Knight $e t a l$., 1997), and natural regulation of CM populations is more strongly influenced by density-dependent factors, such as crop load and available overwintering sites (Ferro et al., 1974).

Effective control of CM requires the repeated applications of cover sprays to maintain an effective toxic residue during the season (Barnes, 1959). Unfortunately, CM has evolved resistance to every class of insecticides applied by growers, from the early use of lead arsenate (Hough, 1928) and DDT (Cutwright, 1954) to the more recently developed insect growth regulators (Sauphanor and Bouvier, 1995) and granulosis virus (Fritsch et al., 2005). The organophosphate (OP) insecticide, azinphosmethyl, has been the primary insecticide used in the USA for CM since the mid-1960s and, surprisingly, resistance was not detected until 1989 (Varela et al., 1993). Resistance mechanisms in CM have included a number of physiological pathways, including altered target sites and amplified detoxification enzymes (Reyes et al., 2007). Cross-resistance among classes of insecticide has apparently reduced the effectiveness of new classes of insecticide, even before they had become widely adopted (Sauphanor and Bouvier, 1995; Dunley and Welter, 2000).

Codling moth pressures in Washington State orchards by the early 1990s had increased significantly, with seasonal moth catches nearly tripling and spray applications doubling from the mid-1980s for many growers (Howell and Britt, 1994). In addition, in response to elevated levels of resistance, many growers increased their application rate of azinphosmethyl and tightened spray intervals. The use of both methyl parathion and chlorpyrifos for CM increased precipitously during this period, causing serious impacts on both pollinators and BC of secondary pests (Gut et al., 1992). Coincidentally, the Alar 'scare' (plant growth hormone) in 1989, the cancellation of phosphamidon (aphicide) in 1990 and the withdrawal of cyhexatin (miticide) in 1992 were harbingers for the eventual loss of even more pesticides registered for use in pome fruits. In particular, the future of the nine OP insecticides registered for tree fruit in 1995 seemed dim.

In 1996 the Food Quality Protection Act was passed, and the Environmental Protection Agency (EPA) was ordered to undertake a reassessment of all pesticide tolerances using a new risk standard of 'a reasonable certainty of no harm'. A new quantitative approach was adopted that considered both the aggregate exposure (all exposure pathways) and the cumulative exposure (all chemicals with the same modes of action considered together), adding up to a tenfold safety factor to protect children. Use restrictions of certain insecticides were tightened by extending worker re-entry periods and preharvest spray intervals and by reducing the total amount of material that could be used per year. By 2006 EPA had reviewed all 9600 pesticide tolerances and revoked 3200, modified 1200 and left 5237 unchanged (Willett, 2006). Currently, there are only four OP insecticides registered in tree fruits in the USA, and a complete phase-out for azinphosmethyl is now scheduled for 2012. 
Quarantine security and phytosanitary requirements have serious impacts on the international marketing of apples and pears (Hansen and Johnson, 2007). For example, Japan requires a postharvest quarantine treatment (probit-9 efficacy) of US cherries with methyl bromide to disinfest fruit for codling moth (MAFF-Japan, 1950). Other countries have strict tolerances for the incidence of pests such as CM, which can lead to rejection of shipments and the eventual shutdown in the market. Postharvest treatments are a significant cost added to the marketing of these fruits, and can have serious impacts on the quality of the treated commodity and risks to human health and environmental degradation (Hansen and Johnson, 2007). These strict international tolerances for $\mathrm{CM}$ force growers to integrate a system of various biological and operational production and postharvest factors that can provide near-quarantine security levels of pest-free produce prior to shipment (Jang and Moffitt, 1994).

Disruption of the natural control of secondary pests in pome fruits by the sprays applied for CM can contribute to the use of additional sprays and subsequent development of resistance in species, such as aphids, leafhoppers and mites (Croft and Bode, 1983). Most noteworthy has been the history of repeated development of resistance to new classes of pesticides by pear psylla, Cacopsylla pyricola (Van de Baan and Croft, 1991) and the tetranychid mites, Tetranychus urticae and Panonychus ulmi (Croft, 1979). The application of additional sprays to manage these OP-resistant pests can cause secondary outbreaks of pests. For example, the western tentiform leaf miner (WTLM), Phyllonorycter elmaella, developed resistance to azinphosmethyl in the early 1980s, and BC of this pest by the eulophid, Pnigalio flavipes, is disrupted by summer use of chlorpyrifos and methyl parathion (Barrett, 1988). The subsequent use of the carbamate, oxamyl, to control leaf miners disrupts integrated mite control, forcing growers to apply costly miticides (Hoyt, 1983).

Conversely, reductions in the use of broad-spectrum sprays can release populations of other pests from chemical control. When broad-spectrum sprays were reduced in MD orchards, minor problems with sporadic pests, such as true bugs, increased (Gut and Brunner, 1998). Of greater concern, however, were the outbreaks of the tortricid leafrollers, Pandemis pynusana and Choristoneura rosaceana, which caused significant levels of fruit injury (Knight, 1995a; Gut and Brunner, 1998). Infestations of orchards by leafrollers can occur from importation of infested nursery stock and the immigration of adult moths from unsprayed, non-bearing blocks of apple, and from cherry orchards after mid-summer harvest (Knight, 2001). While a number of parasitoids can attack these leafroller species, parasitism levels are typically low in conventional orchards (Brunner and Beers, 1990). The use of OP insecticides in the spring and summer for these pests further destabilizes secondary pest populations (Beers $e t$ al., 1998) and has selected for resistance in some populations (Smirle et al., 1998). Selective control of leafrollers is possible with Bacillus thuringiensis (Bt) but the level of control is variable (Brunner, 1994). MD for leafrollers is an added expense, and preliminary trials were only marginally effective due to the relatively high population density of these polyphagous pests and their dispersal capabilities (Gut et al., 1992).

Studies prior to CAMP had demonstrated that BC of secondary pests was not significantly improved when growers reduced their use of broad-spectrum sprays for CM (Howell and Britt, 1994; Knight, 1995a; Gut and Brunner, 1998). For example, the population densities of generalist aphid predators and an egg parasitoid of white 
apple leafhopper (WALH), Typhlocyba pomaria, were higher, but pest levels were unaffected in sex pheromone-treated orchards (Knight, 1995a; Gut and Brunner, 1998). However, the full potential of BC was difficult to assess in these studies as growers only marginally reduced their use of pesticides for secondary pests (Knight, 1995a). The often marginal effectiveness of the available selective insecticides ( $B t$ for leafrollers, soaps for aphids and oil for CM eggs) was a significant constraint in 1995.

Organic tree fruit production increased dramatically, from 1988 when the certification programme began in Washington State with 11 growers farming 40 ha, to 1990 with 100 growers farming 800 ha. A small survey of organic apple-growing practices in 1990 found that orchards were treated, on average, with 14 botanical and microbial sprays per season for CM, yet many orchards still suffered high levels of fruit injury (Knight, 1994). A high proportion of organic growers adopted MD after 1991, but this approach was often ineffective when used as the sole tactic to manage high population densities of CM (Trimble, 1995).

One major constraint common in implementation of IPM technologies has been the establishment of effective systems of information delivery to participants (Travis and Rajotte, 1995). Traditionally, growers obtain information from a large variety of sources, including university extension activities (meetings, publications and field demonstrations), fieldmen, consultants, agricultural supply companies, packing houses and cooperatives. However, acquiring real-time information concerning pest populations in surrounding orchards is more difficult. While some growers may know something about the pest pressures in the adjacent surrounding orchards, they are unlikely to be able to assess pest pressures impacting them from more distant sources.

A number of farm operational factors have negative impact on the management of CM. Many orchards (60\% in the Yakima Valley; Howell and Maitlen, 1987) are irrigated with overhead sprinklers. Overhead irrigation can wash off spray residues, forcing growers to apply higher rates of insecticides and to spray more frequently (Howell and Maitlan, 1987). Similarly, the use of evaporative cooling to reduce sunburn can remove residues and require similar increased spray use in orchards (Williams, 1993). Storage and transport of bins can introduce CM infestations into clean orchards (Newcomber, 1936; Proverbs and Newton, 1975).

Asynchronous emergence of adult moths from bin piles can create unexpected periods of CM activity (Higbee et al., 2001). This problem is heightened because bins are introduced into orchards at variable time periods during the season, and the strong temperature gradient that exists from the inside to the outside of large bin piles can extend the moth's emergence period (Higbee et al., 2001). Finally, attaining complete coverage and fruit protection in large, three-dimensional tree canopies is difficult (Byers et al., 1984). The deposition patterns achieved by growers vary widely, and tractor speed, nozzle type, water volume and air velocity all have a significant impact on these (Howell and Maitlen, 1987).

Codling moth has always been a greater problem on orchard borders rather than in the interior (Madsen and Vakenti, 1973; Gut and Brunner, 1998). Moths, both immigrating into and emigrating out of orchards, pool along the borders resulting in higher densities of injured fruits (Knight, 2007). In addition, spray coverage can be poor along the edges of orchards. The distribution of sex pheromone along borders is also reduced by higher wind speed and turbulence (Milli et al., 1997). 
Monitoring CM with sex pheromone-baited traps is widely practised by growers (Riedl et al., 1986). A number of factors influence moth catches, including a rapid degradation of the sex pheromone within lures (Knight and Christianson, 1999). Thresholds of moth catches have been used as recommendation for the application of insecticides, but the frequent occurrence of 'false negatives', where traps fail to detect local infestations, is a particular problem for MD orchards (Knight and Light, 2005). Recommendations for monitoring $\mathrm{CM}$ in $\mathrm{MD}$ orchards have suggested that growers should use a higher density of traps and replace lures more frequently, practices that increase monitoring costs (Gut and Brunner, 1996).

Mating disruption prior to CAMP was used on 3800 ha in Washington State in 1994 (see Fig. 9.1). The original Isomate-C dispenser was a clear polyethylene tube characterized by a rapid reduction in its emission rate and increased degradation of the pheromone when placed in full sunlight (Brown et al., 1992). A number of factors were known to influence the performance of MD for codling moth, such as dispenser characteristics, pest population density and an orchard's isolation and topography (Charmillot, 1990). For example, MD failed in only one site, Y6, in the 3-year Yakima Valley study (Knight, 1995b). This orchard had a number of poor characteristics that lessened the likely success of MD: a high initial population of $\mathrm{CM}$, a $6 \%$ slope, a high proportion of missing trees and an uneven orchard canopy (tree heights ranged from 2 to $5 \mathrm{~m}$ ). Specific studies addressing the optimal use of the Isomate-G dispenser for CM MD - such as characterizing the seasonal dispenser emission rate, the influence of dispenser density and positioning within the canopy and the role of sex pheromone blend - were not sufficiently characterized until 1995 (Knight, 1995b; Knight et al., 1995; Weissling and Knight, 1995).

The cost of Isomate-C dispensers in 1991 started at US $\$ 326 /$ ha and application costs, depending on the method used by growers, varied from US $\$ 27$ to $69 /$ ha (Knight, 1995a). This initial cost of MD was equivalent to four applications of azinphosmethyl, but most growers in Washington State were applying more than

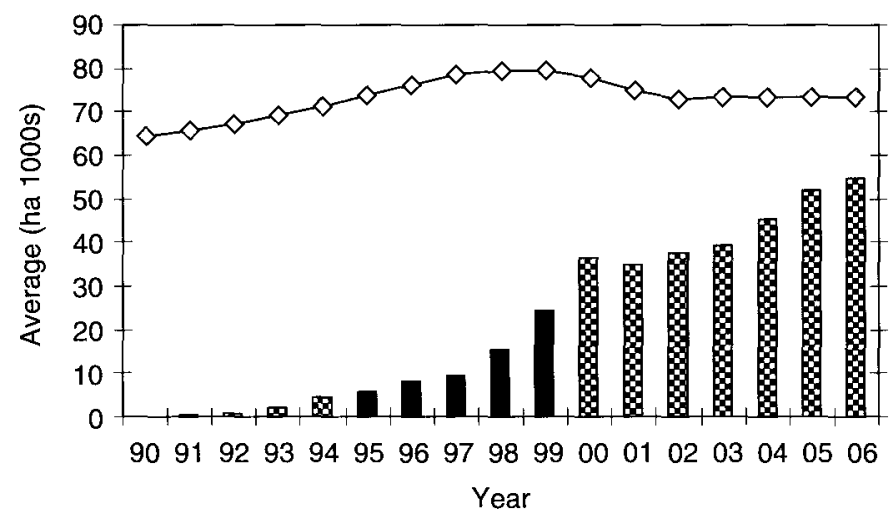

Fig. 9.1. The acreage of total apple and pear production $(0)$ and acreage treated with sex pheromones (vertical bars) for codling moth in Washington State, 1990-2006. The acreage treated during the 5-year codling moth areawide management programme (CAMP) is shown by solid bars. 
three sprays per season (Knight, 1995a). An economic break-even analysis found that the cost of MD would have to decline by $30-73 \%$ to be equivalent to the growers' then current spray programmes (Williamson et al., 1996). Furthermore, this analysis did not include the grower's increased cost of monitoring of MD orchards. Perhaps, in response to both its higher cost and variable effectiveness, over one-third of growers surveyed from 1991 to 1994 had stopped using this new technology (Howell and Britt, 1994).

\section{Factors Available for Successful AWPM Implementation}

There are many constraints that impact the management of CM and the various secondary pests in tree fruits. However, there are also a number of very important factors that were in place in the early 1990s that facilitated the development of effective AWPM programmes. CM has a narrow host range, and in the major tree fruit growing regions in the western USA there are not a large number of unmanaged orchards or large sources of CM outside of commercial orchards (Barnes, 1991). In general, CM populations are maintained at very low levels in commercial orchards and most growers in Washington State prior to 1995 applied no more than two sprays per season (see Table 9.1). Pest boards are funded in nearly every county to deal with the presence of pest problems emanating from unmanaged sites, and are usually mandated either to spray orchards or to remove trees at the owner's expense.

Table 9.1. Survey of insecticide usage for management of codling moth and leafrollers in Washington State, USA, apple from summaries of agricultural chemical usage in 1991, 1995, 1999 and 2005 (from NASS reports).

\begin{tabular}{|c|c|c|c|c|}
\hline \multirow[b]{2}{*}{ Insecticide } & \multicolumn{4}{|c|}{ Mean no. of sprays (percentage of area treated) } \\
\hline & 1991 & 1995 & 1999 & 2005 \\
\hline Azinphosmethyl & $2.8(90)$ & $3.3(94)$ & $2.3(78)$ & $1.8(72)$ \\
\hline Chlorpyrifos $^{a}$ & $1.4(65)$ & $1.3(80)$ & $1.3(65)$ & $1.1(58)$ \\
\hline Phosmet & $2.1(9)$ & $2.4(2)$ & $2.0(7)$ & $1.4(15)$ \\
\hline Ethyl parathion & $1.0(32)$ & $-c$ & $-^{c}$ & $-^{c}$ \\
\hline Methyl parathiona & $1.5(28)$ & $1.2(19)$ & $1.1(5)$ & $-c$ \\
\hline Bacillus thuringiensis ${ }^{b}$ & NA & $2.2(21)$ & $2.0(19)$ & $1.3(18)$ \\
\hline Spinosad & NA & NA & $1.4(39)$ & $1.3(62)$ \\
\hline Acetamiprid & NA & NA & NA & $1.2(41)$ \\
\hline Thiacloprid & NA & NA & NA & $1.1(2)$ \\
\hline Novaluron & NA & NA & NA & $1.2(12)$ \\
\hline Lambda-cyhalothrin & NA & NA & NR & $1.7(3)$ \\
\hline Granulosis virus & NA & NR & NR & $1.5(9)$ \\
\hline
\end{tabular}

NA, not available; NR, no records.

aThese insecticides are applied for control of either codling moth or leafrollers.

bThese insecticides are applied for control of leafrollers.

"No longer registered for use in apple. 
Experience developed for the use of CM MD during the 3-year transition programmes conducted in the Yakima and Wenatchee Valleys in Washington State (Brunner et al., 1992), the first coordinated areawide programme developed by five pear growers in Randall Island, California, in response to OP resistance (Varela $\ell$ tal., 1993) and the use of MD on a large, contiguous apple block ( 400 ha) by a single grower in north-central Washington (Knight, 1992) were key events that provided the industry with an important early assessment of the potential outcome of adopting MD. Risk assessment indices were developed to assess the probable success of MD based on orchards' previous and current levels of fruit injury and moth catches in sex pheromone-baited traps (Gut and Brunner, 1996). Four risk categories (very low, low, moderate and high) were created, each with associated guidelines for the supplemental use of insecticides and suggested dispenser application rates (Gut and Brunner, 1996). Recommendations for the monitoring and managing of secondary pests in MD orchards were also outlined (Gut et al., 1995).

Despite the detection of incipient levels of resistance to azinphosmethyl in some orchards, the majority of CM populations monitored remained susceptible (Varela et al., 1993; Knight et al., 1994). The availability of both methyl parathion and chlorpyrifos, which exhibited negative cross-resistances with azinphosmethyl (Dunley and Welter, 2000), allowed growers to use other effective materials if needed. The existing integrated mite management programme present in most orchards was largely created by the development of resistance by the phytoseiid mites to azinphosmethyl (Hoyt, 1969). This was also true for the effective BC of the western tentiform leaf miner by P. flavipes (Beers et al., 1993).

Several new selective approaches were developed to manage leafrollers in the early 1990s. $B t$ sprays could be optimized if the first spray was applied at the maximum rate, delayed until petal fall and applied only with a forecast of extended warm weather (Knight, 1997). Studies found that significant BC of leafrollers could develop in orchards with selective programmes (Brunner, 1992). Demonstrations that a generic, partial sex pheromone blend could be effective for several of the suite of leafroller species attacking a number of horticultural crops in western USA increased the likelihood of commercial development (Knight, 1996; Knight et al., 1998; Knight and Turner, 1999). The first testing of MD in the USA for leafrollers in larger (16 ha) replicated orchard blocks demonstrated the effectiveness of this selective approach (Knight et al., 1998).

Several improvements were made with sex pheromone-based products early in the 1990s. A new Isomate-C Plus dispenser was developed that significantly reduced the degradation of the pheromone and had an improved seasonal emission profile (Gut et al., 1995). Competition among several small companies registering MD dispensers for CM caused significant reductions in the retail price of dispensers. The application cost of MD declined as growers developed more efficient methods of applying dispensers. For example, the total cost of Isomate-C dispensers and their application dropped US\$100/ha from 1991 to 1993 (Knight, 1995a). In particular, the cost of MD dropped most dramatically for growers who cut their application rate of dispensers. Advantages - such as no re-entry waiting periods, compatibility with overhead irrigation, lowered risk of incidence of insecticide resistance, improved worker safety and no container disposal - all combined to generate growing interest in this technology (Brunner et al., 1992). 
A few studies demonstrated that GM could be managed in organic orchards successfully using MD. Successful organic production was demonstrated in Canada by removal of injured fruits during the season, banding of trees to remove overwintering larvae and the use of sex pheromones (Judd et al., 1997). Gut and Brunner (1998) were able to clean up an infested organic orchard using two applications of MD dispensers and 16 supplemental sprays of ryania and $B t$. In subsequent years, CM was effectively managed using only MD in this orchard.

Management of the problematic orchard borders was achieved with a number of approaches. Typically, growers sprayed borders of MD orchards with insecticide sprays (Knight, 1995a; Gut and Brunner, 1998). A few growers applied additional dispensers on borders or extended the pheromone-treated area to include adjoining blocks of hosts or non-hosts, windbreaks or fencerows (Gut and Brunner, 1998). Treating larger, contiguous areas reduced the relative size of orchards' borders relative to the total area, and subsequently the importance of these areas.

Several institutional factors were present prior to CAMP that strongly benefited the development of AWPM. Thresholds and sampling plans were developed for nearly all secondary pests (Beers $e t$ al., 1993). A predictive phenology model to time the first cover spray to coincide with the start of CM egg hatch had been validated and was widely used (Brunner et al., 1982). Weather monitoring networks, such as Washington State's Public Agricultural Weather System (PAWS), were established and provided input for a number of insect, disease and plant models that growers could readily access. The various land grant university extension services were relatively well-funded, gathering and disseminating information for growers through publications, workshops, field days and via telephone, fax, mail and the fledgling Internet. In addition, private consultants and fieldmen representing chemical supply companies, cooperatives and packing houses provided monitoring services and made informed management recommendations for growers.

The tree fruit industry in the western USA has a history of providing generous support for pest management-related research (Ing, 1999). The first research project funded by the Washington Tree Fruit Research Commission (WTFRC) for CM MD (US\$6000) was granted in 1991, along with a budget of US $\$ 100,000$ for entomological research (Ing, 1992). Levels of funding by WTFRC for entomological research increased by US $\$ 100,000$ each year prior to CAMP, with over US $\$ 200,000$ granted for CM and leafroller MD research alone in 1994 (Ing, 1995).

\section{The Structure of CAMP}

The AWPM programme was developed as a partnership of federal agencies, university researchers and extension personnel, state departments of agriculture and the private sector, including growers, commodity groups and other stakeholders (Calkins and Faust, 2003). CAMP was constructed as a coordinated programme requiring active grower involvement to apply environmentally sound, effective and economical approaches over large, contiguous areas of tree fruit production (Calkins, 1998). The objectives of the programme focused primarily on entomology and did not incorporate new approaches for either horticultural or postharvest control. 
The specific objectives were to:

- $\quad$ Reduce the use of neurotoxic insecticides by $80 \%$.

- Demonstrate that MD worked better when applied over large areas, partially through the need for less pheromone and lower costs.

- Develop companion technologies to supplement MD that have a lower cost.

- Increase the role of BC in managing pest populations.

- Develop an effective areawide monitoring programme and establish the use of thresholds.

- Improve worker safety.

- Improve public perception that fruit production is safe for consumers (Calkins et al., 2000).

The expected benefits of this programme were that the AWPM programme would be as effective as, or better than, conventional programmes for CM, reduce the need for sprays for other pests and reduce the use of broad-spectrum insecticides. These benefits would be reached through coordination and optimization of growers' actions, including expanded monitoring, adoption of action thresholds and the use of selective and efficacious tactics (Calkins et al., 2000). A transition to this new programme for growers was eased by providing a direct subsidy to growers within the pilot projects for 3 years (US\$125/ha), as well as providing funding for each project to hire a manager and supplies. The intention of the project was that government involvement would end after 5 years and AWPM would be maintained through a sustainable framework created by farmers, consultants and local organizations (Calkins and Faust, 2003).

Five pilot projects were established in the western USA, with one project in California and Oregon and three in Washington State. These five sites were selected to encompass a broad geographical area and included a range of climatic conditions, fruit varieties and cultural practices, as well as differences in pest management practices. A few basic criteria were established to identify the suitability of each site: (i) a typical fruit production area in the region with consistent pest pressure from CM and other pests; (ii) producers within the project would be willing to cooperate and share costs; and (iii) each group would have the ability to construct a local organizational structure to support and continue the use of AWPM (Calkins and Faust, 2003).

Similar management tactics were applied to orchards in all projects (Calkins, 1999). Orchards were treated with the full rate of sex pheromone dispensers (Isomate-C+ was the sole product used in all but one project), and growers were encouraged to apply one spray of azinphosmethyl to lower the initial population density of CM. All orchards were monitored with a high density of traps (one per ha) baited with high-load sex pheromone lures, and placed in the upper third of the canopy. Moth catch thresholds were established to recommend the use of supplemental sprays during the second moth generation. Secondary pests and natural enemies were closely monitored in a proportion of blocks, and the supplemental use of insecticides for secondary pests was based on the use of accepted thresholds (Calkins, 2003). Comparison orchards outside of the projects were selected based on their similarity in cultivars and horticultural practices, but these conventionally managed orchards were not treated with MD.

The organization of CAMP was structured into four subsections: administration, implementation, research and education. Dr Calkins, the research leader at the 
ARS laboratory in Wapato, Washington, was the project's overall administrative leader and controlled the funding provided to the various pilot projects, research projects and education and extension outreach efforts. An Areawide GM Industry Advisory Committee comprised of a cross-section of industry leaders met with the administrators, project coordinators and researchers to review progress at each project site and discuss the related ongoing research concerning control of CM and other orchard pests. This group then reported their findings to other committees, such as the Washington State Horticultural Association Agriculture Chemical Committee, within the industry of each state. ARS administrators from the beginning emphasized the importance of bringing growers into the process early.

Implementation efforts in each of the five original CAMP sites were managed by scientists at the universities and at ARS. Funding provided to each of the pilot projects ranged from US $\$ 50,000$ to 185,000 per year depending on the size and specific needs of the project. The first year of the projects was the most difficult due to some concern by growers that they were being forced, even if by peer pressure, to join a government-mandated programme. Before becoming active participants, growers had to be assured that they had control of the project. The use of the 3-year subsidy appeared to have been a very effective enticement for growers to join the programme.

\section{CAMP projects}

Howard Flat, Washington, was characterized as an isolated, typical tree fruit production area (90\% apple) in north-central Washington, with flat topography. A preliminary coordinated study began in 1994 using MD on 125 ha. The funding provided by CAMP increased the size of the project to 486 ha, with 176 blocks farmed by 34 growers. The Howard Flat Management Board was formed with five fruit industry fieldmen (individuals who worked for local packing houses and agricultural chemical distribution companies) and three local growers. A Technical Advisory Committee was created with a group of applied entomologists (university and government researchers), and weekly breakfast meetings were held from the start to the end of each growing season. A project coordinator was hired to handle the daily activities, such as orchard monitoring and data summation. Monitoring information from all blocks was disseminated through weekly meetings, postings at a centrally located kiosk within the project, an electronic bulletin board and a monthly newsletter.

Parker Heights was considered to be a challenging area (190 ha), characterized by mixed-crop production (80:20 apple and pear) and situated across a hilly terrain. Pome fruit orchards were interspersed among 60 ha of stone fruit (cherry and peach), creating an extensive array of MD-treated borders in the project. An ARS employee served as the site coordinator and managed the project, along with a steering committee of two growers and three fruit industry fieldmen.

Oroville was a unique site consisting of 154 ha situated on the Canadian border on either side of Lake Osoyoos. Thirteen growers farmed 65 orchard blocks with 90\% apple production. All orchards received weekly releases of sterilized CM adults provided by the Canadian Sterile Insect Release Program in Osoyoos, British Columbia (Bloem and Bloem, 2000). ARS hired a project coordinator, released the 
moths, monitored the orchards and maintained an office on site where growers could access project information and discuss issues with the coordinator's staff.

Medford, situated in southern Oregon, was characterized by a flat topography and $90 \%$ of its 121 ha were planted in 13 cultivars of pear and farmed by seven growers. The project was organized by Oregon State University personnel and began in 1994 on 30 ha, using a selective programme based on MD and repeated applications of horticultural oil for CM. The project had the same coordinator for all 5 years, and bi-weekly meetings were held with all participants during each growing season.

Randall Island was the first coordinated areawide project for CM and was started by five Bartlett pear growers on 308 ha in 1993, with support from the University of California in Berkeley, California. The project focused on the use of MD to combat the development of high levels of OP resistance (five- to eightfold) in local CM populations. Initially, growers used two dispenser applications and evaluated the use of rotations of methyl parathion and azinphosmethyl in combination with MD to manage $\mathrm{CM}$ and $\mathrm{OP}$ resistance.

CAMP funded 17 one-year sites from 1997 to 1999 (see Table 9.2). Each project received US $\$ 40,000$ to hire a project manager and purchase basic supplies, such as traps and lures. The criteria used to select these new sites were that they be comprised of $>160$ ha of contiguous orchards, used MD and be farmed by at least five growers. Selection preference was given to sites that: (i) had some prior experience with MD; (ii) were farmed mostly by small growers; (iii) had a unique feature that would help extend the fruit industry's knowledge and adoption of the areawide control approach - such as pest complex, pest pressure or the site's topography or location; and (iv) could demonstrate a strong likelihood of continuing the project after the 1-year support ended (Calkins, 1999).

\section{Support provided for research}

CAMP provided nearly US\$1 million to support various research projects that:

- Addressed improved monitoring of CM and leafrollers.

- Quantified the atmospheric sex pheromone concentration within orchards and the release rates of lures and dispensers.

- Improved monitoring for stink bugs.

- Enhanced BC of CM, leafrollers and the tarnished plant bug, Lygus lineolaris, through classical and augmentative releases of parasitoids.

- Assessed the importance of biodiversity and the population dynamics of selected $\mathrm{BC}$ predator species in orchards.

- Characterized the impact of seasonal spray programmes of horticultural oil and kaolin particle films on pest management and plant growth.

- Tested new technologies for MD of CM and leafrollers.

Proposed projects were submitted on a yearly basis to CAMP and evaluated by a panel of ARS scientists, with recommendations provided by representatives of WTFRC and the California Pear Advisory Board. The goals of this collaborative project were to avoid duplicative funding by WTFRC and/or the Pear Pest Management 
Table 9.2. General characteristics of the project sites established during the CAMP programme.

\begin{tabular}{|c|c|c|c|c|}
\hline Year (s) & Location & Crop mixa & Hectares & No. of growers \\
\hline 1995-1999 & Randall Island, CA & $0: 100$ & 308 & 5 \\
\hline 1995-1999 & Medford, OR & $20: 80$ & $121-202^{b}$ & $5-7^{b}$ \\
\hline 1995-1999 & Parker, WA & $80: 20$ & $190-224^{b}$ & $7-11^{b}$ \\
\hline 1995-1999 & Howard's Flat, WA & $90: 10$ & $486-688^{b}$ & $36-57^{b}$ \\
\hline 1995-1999 & Oroville, WA & $95: 5$ & $154-526^{b}$ & $66-09^{b}$ \\
\hline 1997 & Progressive Flat, WA & $100: 0$ & 243 & 25 \\
\hline 1997 & Brewster, WA & $96: 4$ & 1902 & 41 \\
\hline 1997 & Manson, WA & $98: 2$ & 410 & 68 \\
\hline 1997 & Wapato, WA & $90: 10$ & 364 & 18 \\
\hline 1997 & Mendocino, CA & $0: 100$ & 223 & 10 \\
\hline 1998 & Chelan, WA & $100: 0$ & 263 & 11 \\
\hline 1998 & E. Wenatchee, WA & $95: 5$ & 202 & 12 \\
\hline 1998 & Quincy, WA & $100: 0$ & 283 & 7 \\
\hline 1998 & Bench Road, WA & $95: 5$ & 506 & 9 \\
\hline 1998 & Moxee, WA & $100: 0$ & 271 & 6 \\
\hline 1998 & Lower Roza, WA & $90: 10$ & 688 & 23 \\
\hline 1998 & Rogers Mesa, CO & $100: 0$ & 243 & 17 \\
\hline 1999 & $\begin{array}{l}\text { Milton Freewater, } \\
\text { OR }\end{array}$ & $100: 0$ & 422 & 20 \\
\hline 1999 & Entiat Valley, WA & $50: 50$ & 565 & 32 \\
\hline 1999 & Highland, WA & $95: 5$ & 690 & 24 \\
\hline 1999 & West Valley, WA & $92: 8$ & 338 & 12 \\
\hline 1999 & Lake County, CA & $0: 100$ & 202 & 9 \\
\hline 1995-1999 & Total (1999) & & 9763 & 533 \\
\hline
\end{tabular}

aRatio of apple to pear within the project.

bFigures increased between 1995 and 1999.

Research Fund in California and to maximize the overall impact of the dollars spent in supporting research. The impact of the CAMP programme was clearly expanded by the acquisition of additional funding to support both research and implementation by the various participants in the project.

\section{Centralized project coordination}

One necessary structural component envisioned to develop an AWPM programme was the establishment of a central authority to run the project (Kogan, 1995). However, due to the large geographical size and number of participants, a centralized authority for CAMP proved to be cumbersome and largely unnecessary to coordinate the activities at each site. Several useful tools were developed at Oregon State University that aided the project, including: (i) a generalized bibliographic database 
for CM; (ii) an online weather data and degree-day web site supporting 102 sites from Oregon, Washington and Idaho, with 20 insect and disease models and crop models;

(iii) GIS tools to develop maps of each of the sites and to summarize moth catches and levels of fruit injury among orchards; and (iv) grower satisfaction surveys in 1995 and 1996.

\section{Orchard monitoring}

One major impetus for growers to adopt MD for CM was the belief that achieving significant reductions in the use of broad-spectrum insecticides for this key pest would allow them also to reduce their use of sprays for secondary pests. Thus, CAMP spent nearly US\$200,000 each year monitoring pests and natural enemies in comparison blocks under areawide MD versus conventional OP-based programmes (Beers et al., 1998). Researchers at Washington State University developed the standardized protocols for monitoring, including sampling plans and data sheets for both apple and pear. Data were collected from a subsample of orchards ( 4 ha blocks) in each of the five original pilot project sites from 1996 to 1999 (sce Table 9.3). In addition, data were collected from apple plots within four large, contiguous orchard sites in Washington State managed by individual growers (GRABS - Growers Resource Acquisition Baseline Study). Unfortunately, an additional objective of this project to 'assess the effect of MD versus conventional management on spray practices for secondary pests and its economic significance' was not completed.

Twelve different types of samples were collected in apple and pear during the project (Beers et al., 1998). The eight samples collected from apple included: (i) the

Table 9.3. Summary of secondary pest sampling conducted in selected orchards (4 ha plots) treated with sex pheromone within areawide projects and compared with similar (tree age, cultivar and training system) conventional orchards.

\begin{tabular}{llccccc}
\hline & & \multirow{2}{*}{$\begin{array}{c}\text { Contiguous } \\
\text { hectares }\end{array}$} & \multicolumn{2}{c}{ No. of blocks sampled (no. of comparison blocks) } \\
\cline { 7 - 7 } Site/state & Crop & of MD & 1996 & 1997 & 1998 & 1999 \\
\hline Oroville/WA & Apple & 526 & $12(6)$ & $5(5)$ & $5(5)$ & $5(5)$ \\
Howard Flat/WA & Apple & 344 & $12(8)$ & $12(8)$ & $12(8)$ & $12(8)$ \\
Parker/WA & Apple & 179 & $14-16(8)$ & $15-17(8)$ & $15-25(8)$ & $13-28(8)$ \\
Parker/WA & Pear & 45 & $9-20(4-8)$ & $9-10(5-9)$ & $9-14(4-6)$ & $15-21(6-9)$ \\
Medford/OR & Pear & 202 & $3(3)$ & $4(4)$ & $4(4)$ & $4(4)$ \\
Randall Island/CA & Pear & 308 & $9-11(2)$ & $8(8)$ & $8(8)$ & $8(8-11)$ \\
Vantage/WA & Apple & 202 & $4(4)$ & $4(4)$ & $4(4)$ & $4(4)$ \\
Brewster/WA & Apple & 486 & $4(4)$ & $4(4)$ & $4(4)$ & $4(4)$ \\
BridgeportWA & Apple & 202 & $4(4)$ & $4(4)$ & $4(4)$ & $4(4)$ \\
Pateros/WA & Apple & 233 & $4(4)$ & $4(4)$ & $4(4)$ & $4(4)$ \\
\hline
\end{tabular}

aGRABS (Grower Resource Acquisition Baseline Study) sites were large, contiguous areas of apple owned by a single grower under MD. 
density of overwintering eggs and levels of parasitism for WALH; (ii) WALH nymphal densities during the first and second generations; (iii) aphid population (Aphis spp.) and natural enemy counts at five time periods during the season; (iv) leaf samples of WTLM mines and parasitism rates during the second and third generations; (v) Campylomma nymph counts during petal fall; (vi) leafroller larval counts for the overwintering and summer generations; (vii) mite binomial and leaf brushing samples; and (viii) fruit damage samples at mid-season and preharvest. The four types of pear samples collected were: (i) pre-bloom cluster samples for mites and psylla; (ii) post-bloom leaf brushing for mites and psylla; (iii) limb taps for psylla and generalist predators; and (iv) fruit damage counts at mid-season and preharvest.

\section{Extension and education activities}

CAMP was extremely active in the collection and distribution of information concerning the various aspects of pest management under the new AWPM programme. An Extension Program Coordinator was hired in 1996 and stationed with Washington State University Extension in Wenatchee, Washington. A similar 2-year extension position was funded in Yakima, Washington, during the last 2 years of the project. Extension personnel were also active in promoting $\mathrm{MD}$ for $\mathrm{CM}$ in both Oregon and California, though no new positions were created.

The Program Coordinator published 31 issues of the Areawide IPM Update Newsletter from 1996 to 1998. This newsletter provided a comprehensive review of research findings and information concerning each of the CAMP sites. Summer IPM tours and winter workshops were held to present the latest findings on the use of MD and the progress of the areawide programmes. The Coordinator produced an informational booklet on using MD and guidelines to establish new areawide projects (Alway, 1998a). Guides were also produced specifically for pear pest identification and monitoring (VanBuskirk et al., 1998; Bush et al., 1999).

\section{Outcome of the CM AWPM Programme}

CAMP was considered a great success by the industry because most growers were able to reduce their use of $\mathrm{OP}$ insecticides and their levels of $\mathrm{CM}$ injury without a noticeable increase in production costs (Calkins, 1999). This generalized result was sufficient to create a 'buzz' and promote a more rapid rate of adoption of MD, starting in 1998 (see Fig. 9.1). However, the specific components of pest management used in each project varied and a clear interpretation of the project's overall results is more nuanced. A number of additional factors affecting the economics of tree fruit production probably impacted the increased rate of adoption of MD that occurred after the conclusion of the project. Of particular importance was the development of OP resistance and the anticipation of use restrictions implemented by EPA for certain OP insecticides (Willett, 2006).

Levels of CM injury were generally higher in orchards during 1994 prior to the start of CAMP, and declined strongly during the 5-year project (see Fig. 9.2a). 
(a)

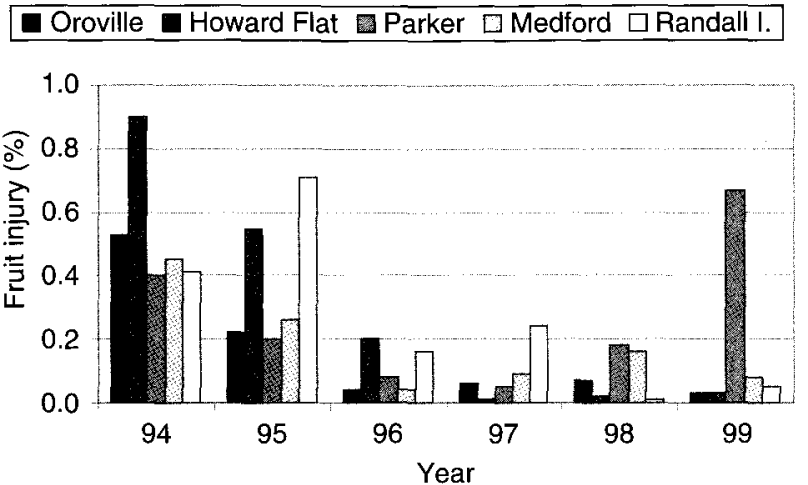

(b)
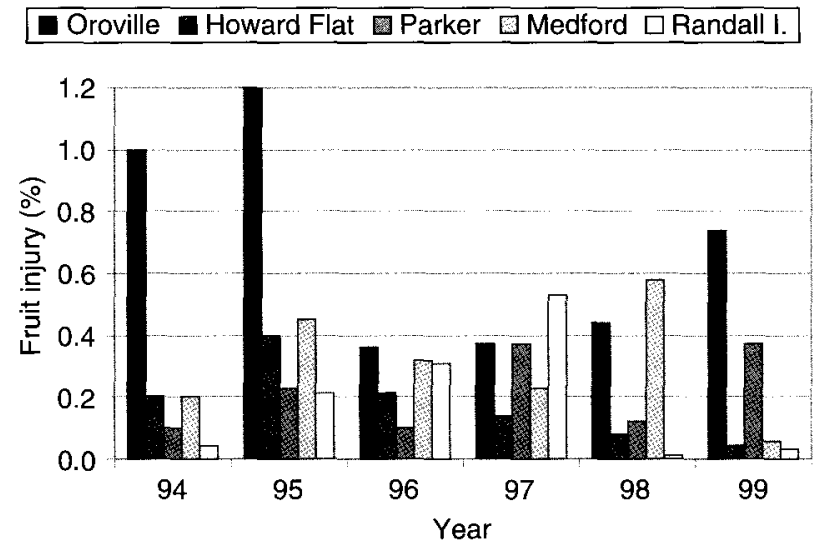

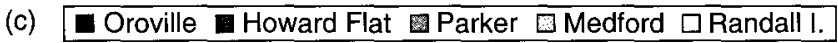

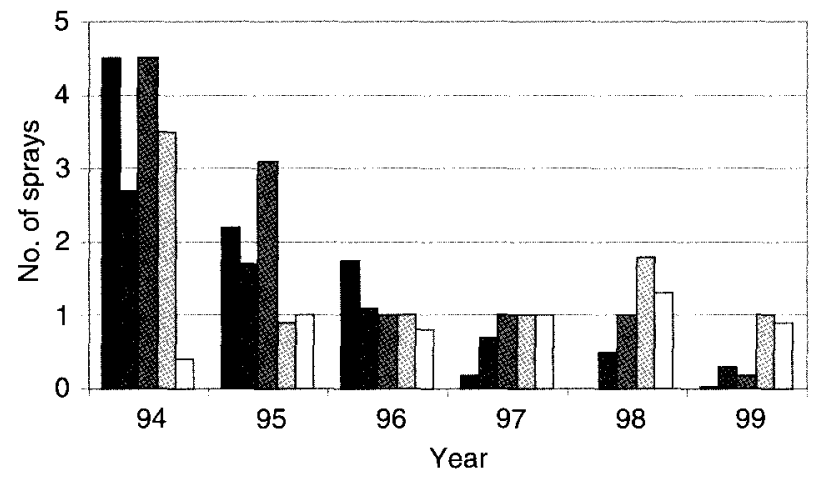

Fig. 9.2. Summary of the extent of (a) codling moth fruit injury; (b) leafroller fruit injury; and (c) organophosphate spraying applied per season for codling moth in the five original CAMP sites prior to the start of the project (1994) and during the 5-year project (1995-1999). 
Injury levels in the first year of CAMP declined in all sites except Randall Island, where 1995 was actually the third year of the project. The ability of growers to reduce their use of supplemental OP sprays at this site during the project's first 3 years (1993-1995) was limited by a continued high pest pressure and elevated levels of OP resistance. CM populations in the later years of the project were significantly reduced by the rotation of methyl parathion and azinphosmethyl during the season and the occasional postharvest use of chlorpyrifos.

The significant increase in CM injury in the last year of the Parker project was also noteworthy (see Fig. 9.2a). The project coordinator hypothesized that this spike was the result of growers sharply reducing their dispenser density from 1998 after the cost subsidy was dropped by ARS (Higbee and Calkins, 2000). An apparent poor correlation of moth counts in traps with pest pressure 'false negatives' in some orchards in this hilly terrain allowed growers to forego sprays, and high levels of fruit injury occurred in 1999 .

Levels of fruit injury by leafrollers were generally higher than CM injury in all of the pilot projects (see Figs 9.2a, b). Interestingly, growers in the Oroville site were not aware of leafrollers being present in their orchards prior to 1994. Levels of leafroller injury increased in all projects in the first year of CAMP (Fig. 9.2b). Injury levels were variable between years in each of the sites, with populations gradually increasing in Oroville, declining in Howard Flat, variable in Parker and declining in the last 2 years of the projects in Medford and Randall Island (see Fig. 9.2b).

The use of OP sprays targeted specifically for CM declined by nearly $75 \%$ in orchards within the five projects compared with either the levels used prior to the project in 1994 or the comparison blocks surveyed during the project (see Fig. 9.2c). The use of sprays declined most precipitously in Oroville, probably due to the supplemental control provided by the SIT programme. Use of OP sprays also declined sharply in Howard Flat and Parker; however, as previously mentioned, the sharp reduction in sprays applied in Parker was correlated with an equally sharp increase in CM injury (see Fig. 9.2a). The use of one seasonal OP application remained consistent in both the Randall Island and Medford pear sites.

In the first year of the project some growers did not spray for leafrollers because of the high cost of MD for CM (Beers et al., 1998). However, in general, leafrollers were a problem in most orchards inside and outside the projects and all growers increased their use of both chlorpyrifos against delayed dormant and methyl parathion during the summer, as well as the use of $B t$ for spring and summer leafroller control (see Table 9.1). Unfortunately, the spray records for materials applied for other secondary pests such as aphids were not summarized from each site.

Sampling of secondary pest and natural enemy populations found a few significant differences between apple and pear blocks in the CAMP versus conventional blocks (see Table 9.4). WALH population densities were lower in CAMP than in conventional blocks only in 1997 (early-summer nymphs) and 1999 (overwintering eggs); however, parasitism levels of the overwintering eggs by the mymarid, Anagrus epos, were higher in all years. No significant differences were found in either the densities of green aphids or their assemblage of generalist predators (coccinellids, syrphids, lacewings, mirids and cecidomyiids) during the study. The density of WTLM was lower and parasitism levels by $P$. flavipes were higher in some samples in 1998 and 1999. The density of phytophagous mites was lower in CAMP only in 1998, but the 
density of predator mites was higher during the last 3 years of the project. In pear, phytophagous mite densities were lower in CAMP only in 1996 and predatory mites were higher only in 1998. The mid-summer density of pear psylla was lower in CAMP from 1996 to 1998 (see Table 9.4).

The assessment of fruit injury from 1996 to 1999 found that CM injury was lower in apple CAMP blocks from 1996 to 1998 (see Table 9.5). Similarly, fruit injury by leafrollers was also lower from 1996 to 1998 . Levels of fruit injury by the western flower thrips, Frankliniella occidentalis, were higher in CAMP in 1997 than in conventional blocks, but Campylomma injury levels were lower in CAMP in 1996. Tarnished plant bug injury was higher in CAMP than in conventional blocks in 1997 but lower in 1999. No significant differences in injury were found between treatments due to the cutworm, Lacanobia subjuncta, the stink bug, Euschistus consperus or green aphids (see Table 9.5). Overall, levels of fruit injury were lower in CAMP than in conventional apple orchards in both 1998 and 1999. Total pear injury was lower in CAMP in both 1997 and 1998, primarily due to lower levels of injury from tarnish plant bug and, in particular, pear psylla in these years (see Table 9.6). No difference was found for levels of injury in pear due to CM, leafroller, L. subjuncta, the grape mealybug, Pseudococcus maritimus, or the stink bug, E. consperus.

Table 9.4. Summary of secondary pest and natural enemy sampling in apple and pear blocks where significant differences were found in the areawide sex pheromone-treated blocks versus those in the comparison conventional blocks, 1996-1999.

\begin{tabular}{|c|c|c|c|c|c|}
\hline \multirow[b]{2}{*}{ Crop/sample timing } & \multirow[b]{2}{*}{ Sample } & \multicolumn{4}{|c|}{$\begin{array}{c}\text { Significant difference in arthropod } \\
\text { population densities in areawide MD } \\
\text { versus the comparison conventional } \\
\text { orchards }\end{array}$} \\
\hline & & 1996 & 1997 & 1998 & 1999 \\
\hline Apple/overwintering & Leafhopper eggs & & & & Lower \\
\hline Apple/early summer & Leafhopper nymphs & & Lower & & \\
\hline Apple/mid-summer & Leafroller larvae & & Lower & Lower & \\
\hline Apple/mid-summer & Mines per leaf & & & Lower & Lower \\
\hline Apple/late summer & Mines per leaf & & & & Lower \\
\hline Apple/mid-summer & Mites per leaf & & & Lower & \\
\hline Apple/late summer & Mites per leaf & & & Lower & \\
\hline Pear/pre-bloom & $\begin{array}{l}\text { Pear psylla eggs } \\
\text { per cluster }\end{array}$ & & & Lower & \\
\hline Pear/mid-summer & Mites per leaf & Lower & & & \\
\hline Pear/mid-summer & Pear psylla per leaf & Lower & Lower & Lower & \\
\hline Apple/overwintering & Parasitized leafhopper eggs & Higher & Higher & Higher & Higher \\
\hline Apple/mid-summer & Parasitism of leaf miners & & & Higher & Higher \\
\hline Apple/late summer & Parasitism of leaf miners & & & & Higher \\
\hline Apple/mid-summer & Predatory mites per leaf & & Higher & Higher & Higher \\
\hline Pear/mid-summer & Predatory mites per leaf & & & Higher & \\
\hline
\end{tabular}


Table 9.5. Summary of percentage fruit injury in the apple blocks treated with sex pheromone (MD) within areawide projects versus conventional blocks (Conv) outwith the Oroville, Howard Flat, Parker, Vantage, Brewster, Pateros and Chelan areawide codling moth (CM) projects.

\begin{tabular}{|c|c|c|c|c|c|c|c|c|c|c|}
\hline Treatment & Year & $\mathrm{CM}$ & Leafroller & Cutworm & Thrips & Campylomma & Lygus & Stink bug & Aphids & Total \\
\hline $\mathrm{MD}$ & 1996 & $0.17^{a}$ & $0.15^{a}$ & - & $0.08^{\mathrm{a}}$ & $0.01^{\mathrm{a}}$ & $0.14^{\mathrm{a}}$ & - & $0.17^{\mathrm{a}}$ & $0.72^{\mathrm{a}}$ \\
\hline Conv & 1996 & $0.34^{b}$ & $0.25^{\mathrm{b}}$ & - & $0.03^{a}$ & $0.05^{b}$ & $0.09^{a}$ & - & $0.09^{a}$ & $0.85^{a}$ \\
\hline MD & 1997 & $0.05^{\mathrm{a}}$ & $0.05^{\mathrm{a}}$ & - & $0.11^{b}$ & $0.07^{\mathrm{a}}$ & $0.15^{b}$ & - & $0.01^{a}$ & $0.44^{a}$ \\
\hline Conv & 1997 & $0.15^{b}$ & $0.18^{b}$ & - & $0.02^{a}$ & $0.07^{a}$ & $0.03^{a}$ & - & $0.02^{a}$ & $0.47^{a}$ \\
\hline $\mathrm{MD}$ & 1998 & $0.09^{a}$ & $0.10^{\mathrm{a}}$ & $0.10^{\mathrm{a}}$ & $0.24^{a}$ & $0.05^{a}$ & $0.06^{a}$ & $0.06^{\mathrm{a}}$ & $0.02^{a}$ & $0.72^{\mathrm{a}}$ \\
\hline Conv & 1998 & $0.60^{b}$ & $0.29^{b}$ & $0.10^{a}$ & $0.01^{a}$ & $0.06^{a}$ & $0.06^{a}$ & $0.08^{a}$ & $0.04^{a}$ & $1.24^{b}$ \\
\hline MD & 1999 & $0.32^{a}$ & $0.47^{\mathrm{a}}$ & $0.20^{a}$ & $0.20^{\mathrm{a}}$ & $0.11^{\mathrm{a}}$ & $0.13^{a}$ & $0.20^{\mathrm{a}}$ & $0.02^{a}$ & $1.65^{a}$ \\
\hline Conv & 1999 & $0.59^{a}$ & $0.92^{a}$ & $0.23^{a}$ & $0.19^{a}$ & $0.22^{a}$ & $0.39^{b}$ & $0.36^{a}$ & $0.05^{a}$ & $2.95^{b}$ \\
\hline
\end{tabular}

Means within year followed by a different superscript letter were significantly different, $P<0.05$. 
Table 9.6. Summary of fruit injury in the pear blocks treated with sex pheromone (MD) within areawide projects versus conventional blocks (Conv) outwith the Parker, Medford and Randall island areawide codling moth (CM) projects.

\begin{tabular}{lccccccccc}
\hline Treatment & Year & CM & Leafroller & Cutworm & Psylla & Mealybug & Lygus & Stink bug & Total \\
\hline MD & $1996^{\mathrm{c}}$ & $0.19^{\mathrm{a}}$ & $0.26^{\mathrm{a}}$ & - & $0.02^{\mathrm{a}}$ & $0.0^{\mathrm{a}}$ & $0.26^{\mathrm{a}}$ & $-^{\mathrm{d}}$ & $0.73^{\mathrm{a}}$ \\
Conv & $1996^{\mathrm{c}}$ & $0.02^{\mathrm{a}}$ & $0.14^{\mathrm{a}}$ & - & $0.09^{\mathrm{a}}$ & $0.0^{\mathrm{a}}$ & $0.62^{\mathrm{a}}$ & $-\mathrm{d}^{\mathrm{d}}$ & $0.87^{\mathrm{a}}$ \\
MD & 1997 & $0.08^{\mathrm{a}}$ & $0.31^{\mathrm{a}}$ & - & $0.52^{\mathrm{a}}$ & $0.03^{\mathrm{a}}$ & $0.48^{\mathrm{a}}$ & $0.03^{\mathrm{a}}$ & $1.45^{\mathrm{a}}$ \\
Conv & 1997 & $0.05^{\mathrm{a}}$ & $0.03^{\mathrm{a}}$ & - & $1.38^{\mathrm{b}}$ & $0.02^{\mathrm{a}}$ & $0.64^{\mathrm{a}}$ & $0.02^{\mathrm{a}}$ & $2.14^{\mathrm{b}}$ \\
MD & 1998 & $0.32^{\mathrm{a}}$ & $0.12^{\mathrm{a}}$ & $0.02^{\mathrm{a}}$ & $1.42^{\mathrm{a}}$ & $0.00^{\mathrm{a}}$ & $0.15^{\mathrm{b}}$ & $0.01^{\mathrm{a}}$ & $2.04^{\mathrm{a}}$ \\
Conv & 1998 & $0.05^{\mathrm{a}}$ & $0.02^{\mathrm{a}}$ & $0.02^{\mathrm{a}}$ & $4.94^{\mathrm{b}}$ & $0.00^{\mathrm{a}}$ & $0.05^{\mathrm{a}}$ & $0.01^{\mathrm{a}}$ & $5.09^{\mathrm{b}}$ \\
MD & 1999 & $0.08^{\mathrm{a}}$ & $0.13^{\mathrm{a}}$ & $0.02^{\mathrm{a}}$ & $0.56^{\mathrm{a}}$ & $0.05^{\mathrm{a}}$ & $0.12^{\mathrm{a}}$ & $0.00^{\mathrm{a}}$ & $0.96^{\mathrm{a}}$ \\
Conv & 1999 & $0.09^{\mathrm{a}}$ & $0.11^{\mathrm{a}}$ & $0.04^{\mathrm{a}}$ & $0.53^{\mathrm{a}}$ & $0.01^{\mathrm{a}}$ & $0.10^{\mathrm{a}}$ & $0.02^{\mathrm{a}}$ & $0.90^{\mathrm{a}}$ \\
\hline
\end{tabular}

Means within year followed by a different superscript letter $(a, b)$ were significantly different, $P<0.05$

Injury by pear psylla, mealybug and sucking bugs was collected only in Medford in 1996.

dAll sucking bug fruit injury was grouped together as Lygus injury in 1986 
Evaluations of the 17 one-year areawide projects found that all growers considered the project to be a success (Coop et al., 1999). In general, growers in these projects used reduced rates of dispensers, except along orchard borders or in problem hot spots. Low-pressure sites were able to use none to one cover sprays, while midand high-pressure orchards used one to two sprays for the first generation and a reduced number of sprays in the second generation, mostly along borders and in hot spots. These spray programmes contrasted with the previous use of the three to five cover sprays that many growers had applied prior to the projects. In general, no CM injury was reported in these sites or, in some cases, injury was confined to a few small areas within each project, usually known hot spots.

The major secondary pest problems experienced in these projects were either from true bugs, such as the western boxelder bug, Leptocoris rubrolineatus, or stink bugs and the noctuid, Lacanobia subjuncta. Leafrollers were a concern for growers in a number of projects, as moth counts in traps were generally very high during the season. Injury levels from leafrollers, however, were low to moderate in only a few orchards. The large (1902 ha) Brewster project included a 200 ha contiguous area that was treated with MD for both CM and leafrollers (Dual MD) for 3 years (Knight et al., 2001). Leafroller injury in the Dual MD project was reduced by $41 \%$, and growers used approximately one fewer $B t$ spray compared with the orchards in the regular MD programme for CM. Despite these promising results leafroller injury was considered too high, and growers dropped the use of MD and switched to newly registered insecticides, i.e. spinosad (see Table 9.1).

\section{Economic Evaluation of the CM AWPM Programme}

Growers have consistently cited the high cost of adopting MD for CM as the major disincentive for them in adopting this new technology (Coop et al., 1999). Prior to CAMP, an analysis found that costs had increased by US $\$ 740 /$ ha for pear growers in Sacramento County, California who made two dispenser applications per season (Weddle, 1994). Similarly, Williamson et al. (1996) found MD was US $\$ 188 /$ ha more expensive than conventional management in Washington State apple orchards. Other economic impacts that influenced grower adoption of MD included the effectiveness of MD, the difficulty in applying dispensers, the uncertainty associated with monitoring CM, the need for increased attention in orchards (US\$80-120/ha to hire a consultant or for scouting) and the increased risk of secondary pest problems (Weddle, 1993).

Proponents have hypothesized from the earliest adoption of MD that growers would experience reduced injury levels in treated orchards, partially because the evolution of OP resistance was curtailing the effectiveness of the current programme in conventionally managed sites (Weddle, 1994); and that enhanced BC would allow growers to reduce their spray bill in the second and subsequent years (Connor and Higbee, 1999). Williamson et al. (1996) suggested that the benefits of this programme would outweigh its costs when dispensers cost less, growers could further reduce their spray use and the proportion of fruit packed could increase in MD orchards. This optimistic analysis, however, suggested that the benefits of adopting MD would be 
reduced by the continued need for growers to spray orchards with other pesticides or crop amendments, such as calcium chloride.

The economic analysis following the 5-year CAMP was similar (Connor and Higbee, 1999). MD could only be cost-effective in a straight benefit-cost analysis if growers reduced their dispenser densities by half in the second and subsequent years and could maintain a reduced spray programme. Unfortunately, this analysis did not include the costs of two 'down side' outcomes: the higher cost of monitoring and the higher risk of new pest problems developing in MD orchards. Again, the potential impact of $\mathrm{MD}$ on $\mathrm{BC}$ was mentioned but not included in the analysis (Connor and Higbee, 1999).

The limited value of these analyses was highlighted by: (i) their failure to include the benefits accrued to growers using MD who developed experience with an alternative technology prior to the loss of OP insecticides; (ii) growers' greater ability to schedule workers to re-enter unsprayed orchards and complete other essential operations, i.e. thinning, irrigation, etc.; and (iii) growers' reduced liability when the potential for worker exposure to OP residues was eliminated.

Interestingly, two analyses found that the cost of implementing a MD-based programme in pear was less expensive than the then-current conventional programmes. Growers in the Medford project reduced their pesticide use by US $\$ 520 /$ ha as compared with conventional growers (VanBuskirk et al., 1999). Total operating costs of production for pear orchards using the $\mathrm{MD}$ aerosol 'puffer' for Lake County, California were marginally higher in the first year of the project, but $3 \%$ lower in the later years (Elkins et al., 2005).

\section{Growers' Responses to the CM AWPM Programme}

Twenty-two areawide projects, including 533 growers farming 9763 ha, were organized within CAMP (see Table 9.2). Nearly all growers responding to a survey were very pleased with the results obtained with AWPM and the organizational structure of the CAMP projects (Coop et al., 1999). This enthusiasm was reflected in the growth in both the size and number of participants in four of the five original sites that occurred during the 5-year period (see Table 9.2). In addition, new groups of growers were eager to join the 17 one-year projects (Calkins, 1999).

The structure of these projects varied in terms of both the information provided to the growers and the actions requested by the participants. Generally, all projects created a structure that allowed groups of growers to meet and discuss mutual problems and interests. Usually, there were highly knowledgeable advisors associated with the projects to help solve problems and answer bug-related questions. Projects implemented intensive monitoring programmes for $\mathrm{CM}$ and often a select group of secondary pests, and these data were summarized and shared among members. The projects allowed growers to manage their pests effectively through scouting, use of action thresholds and reliance on selective integrated tactics. The outcome of nearly all of these projects was to corral a group of growers together and transform them all into practitioners of IPM through greater knowledge and the use of 
research-based programmes. The successes of the projects were in direct proportion to the intensity of the grower involvement in the group (Knight, 1999).

The number one factor indicating the potential for success has been the group's efforts to clean up the problem orchards in their area. Every successful project included the previously non-participating (NP) grower. For example, the successful grassroots movement at Howard Flat eventually convinced 34 of the 36 growers to join the project. In Oroville, all but one grower joined. NP growers had a number of reasons for not joining the projects: some were against government programmes of any kind; others did not want to work closely with their neighbours either because of past grievances or due to a fear that they would be criticized or lose their management independence. Many growers were initially sceptical of the efficacy of the programme or felt that it was too expensive. And, perhaps the number one reason why pockets of CM existed initially in each of the projects, was because some farmers did not farm full-time and because events in their personal life prevented them from effectively focusing their management skills (Knight, 1999). Areawide problems with CM were dramatically reduced once these growers joined with their neighbours.

Conversely, the major reasons why growers joined the project were because they saw that it was not a top-down government programme; growers in the projects actively reached out to educate and persuade others to join; and, after the first year, the programme was demonstrated to be working and other growers realized they could save money and avoid some of the pesticide-related headaches by joining the project.

\section{Unexpected Outcomes of the CM AWPM Programme}

Immediately following the first registration of CM MD in the USA, growers expressed their concern that MD was too expensive (Knight, 1995a). The initial implementation of CAMP required that growers receive a subsidy of $\mathrm{US} \$ 125 /$ ha (Kogan, 1995). From the beginning, growers adopting MD seemed to push the limits of this technology by stretching the established orchard risk categories to allow them to reduce their dispenser density (Gut and Brunner, 1996). For example, by 1997 only $55 \%$ of Washington State growers were using the full rate of pheromone (Alway, 1997), and this had declined further to $27 \%$ by 1998 (Alway, 1998b). The potential negative impact of reducing dispenser density on GM management could be observed in the Parker CAMP site (see Fig. 9.2a). While growers reduced their use of MD, they also continued to apply broad-spectrum insecticides for CM on more than $80 \%$ of orchards (Alway, 1998b). This grower-developed programme did not allow CAMP to quite achieve its goal of reducing OP use by $80 \%$ (see Fig. 9.2c).

The relative importance of $\mathrm{BC}$ in the CAMP projects was similar to the earlier results found in the 3-year transition studies conducted in individual orchards (Knight, 1995a; Gut and Brunner, 1998). In both studies, growers saw an increase in $\mathrm{BC}$ but few significant reductions in most secondary pest populations (Beers et al., 1998). The one exception was the significant reductions that occurred in pear psylla populations in the Parker and Medford pear projects (see Table 9.6). Also, similar to findings from earlier studies, certain pests became more important in MD orchards 
(Brunner, 1999). For example, the grape mealybug increased gradually in the Parker site in both apple and pear (Higbee and Calkins, 2000). Leafrollers became a much more important problem requiring specific sprays in all sites.

Sucking bugs, such as stink bugs and tarnish plant bug, were major problems in some orchards, particularly along their borders. The noctuid, $L$. subjuncta, was a new pest for growers that caused serious problems in some blocks (Landolt, 1998). Nevertheless, other potential pests - such as the lesser appleworm, Grapholitha prunivora, which had become a pest in commercial apple orchards in the eastern USA (Krawczyk and Johnson, 1996) and is known to be present in wild hosts such as hawthorn and native plum in the Pacific north-west (Brown, 1953) - did not become a problem.

Apple and pear production is ultimately not driven by CM management success but by the economics of farm management. By 1999 the economics of tree fruit production were very poor for growers, and this led to both an overall reduction in the area under production and a noticeable slowing in the adoption rate of MD (see Fig. 9.1). In particular, some growers with older varieties such as Red Delicious went out of business, as did many smaller operations. Other orchards were replanted with wine grapes, cherry or stone fruit. The continued sprawl of towns and cities has forced the conversion of many orchards into rural housing developments. Orchards owned by absentee investment groups and speculators were managed with a thin array of low-cost inputs. These financial conditions led to neglect of some orchards, and CM population levels skyrocketed in some districts. Pest control boards became largely ineffective due to the abundance of problem sites. In many former CAMP sites it took about 3 years for pest problems to build to the levels existing prior to the project.

The ARS-funded project effectively brought together personnel from government, industry and several universities. Tremendous successes were reached in the implementation of AWPM projects, in new research discoveries and in outreach efforts to educate the industry. Not unexpectedly, a few problems occurred with the functioning of such an independent group of experts. The group did not easily adopt the AWPM tenet of having a centralized structure for programme coordination and data collection and dissemination (Kogan, 1995), as some project leaders were hesitant to share information. Control of research funding by ARS created some dissension among researchers when their projects were not fully funded. The unity of the group appeared to break apart by the end of the project, and a summary report was never completed.

\section{Future Prospects for the CM AWPM Programme}

CAMP was an extremely well-funded project, well received by growers and the industry and was clearly influential in the shift that has occurred in tree fruit pest management away from OP-based programmes. CAMP demonstrated that MD could substitute for some use of insecticides, but also emphasized that insecticides are still needed to maintain pest populations at low levels. The use of MD for CM has continued to grow since CAMP ended, and comprises nearly $75 \%$ of the production 
area in Washington State (see Fig. 9.1). Today, with such a large proportion of orchards under MD, there are many contiguous areas treated with MD but, in general, these growers do not work together.

Developing and maintaining a coordinated approach is more difficult than having all growers in a region adopt a similar technology. For example, pear growers in Lake County adopted the use of an areawide grid of aerosol puffers for MD (Shorey and Gerber, 1996). The University of California Extension, with some support from CAMP, ran a demonstration programme for 3 years in this area, and this has been smoothly adopted by the local private consultants (PCAs). Today, these pear growers are on autopilot for control of $\mathrm{CM}$, while the management of secondary pests varies widely among orchards (Elkins, 2002).

Few coordinated AWPM programmes exist today. Government support was necessary in organizing the 22 CAMP projects and it appears that in most regions there is not sufficient organizational structure for growers to maintain their own projects without government funding. Various factors caused projects to dissolve following the CAMP programme. Many projects were fragile, consisting of growers expressing a stereotypical American Wild-West 'go-it-alone' mentality. Projects such as Rogers Mesa in western Colorado were abandoned as growers switched production from apple to stone fruits. Howard Flat lost a large proportion of its tree fruit production due to poor economics and the steady usurpation of orchards by rural real estate development. Some projects were able to function for more than one year with CAMP funding or by obtaining additional government funding or working within funded research projects. Having a few large, contiguous blocks of orchards monitored by one PCA has allowed several large areas to continue under a centralized stewardship.

Other projects, where growers worked with multiple PCAs or sent their fruit to several cooperatives or packing houses, have tended to dissolve. Some such as Brewster were able to exist for a few years due to a combination of factors, such as stretching their use of CAMP funds, obtaining additional government funding, working with a government-funded research project and by forming a non-profit organization that could allocate participants a fee to fund a centralized monitoring and data dissemination programme. However, this project ended after 5 years due to poor farm economics and a lack of a strong and unified grower commitment to the project.

Today, only two of the original 22 CAMP projects remain: Ukiah Valley in California and Milton Freewater in Oregon. Ukiah Valley started in 1996 with a grant from EPA and then extended the 1-year CAMP funding in 1997 to fund a 3-year project headed by University of California Extension personnel. Pear growers farming 536 ha formed the non-profit Ukiah Pear Grower Association and continue to allocate growers a fee to hire a trap checker who monitors orchards and distributes information to all participants. Unfortunately, the cohesiveness of the project is threatened by both the reduced problems in managing CM and the emergence of new pests. The Milton Freewater growers organized themselves through the Blue Mountain Horticultural Society in 1998, and have maintained a coordinated project on nearly 1000 ha in north-eastern Oregon. Interestingly, not all growers use MD in the project. Growers are assessed at US $\$ 45 /$ ha to fund a monitoring programme. Data are e-mailed to all growers and the various warehouses in the district and are 
posted on several bulletin boards within the project site. General information is exchanged, and the group's cohesion is maintained at weekly meetings held at the local extension office.

In summary, 7 years after the end of CAMP there remains a general lack of local coordination between growers' pest management activities, but there has been an exponential increase in the knowledge of how to implement MD (Brunner et al., 2007). CAMP was followed by other, well-funded USDA projects, which achieved further improvements in MD and tested alternative, selective tactics to replace the use of OPs (Initiative for Future Agricultural and Food Systems, Risk Avoidance and Mitigation for Major Food Crops Systems, American Farmland Trust and Sustainable Agriculture Research and Education). Unfortunately, GM remains the number one pest problem for most growers and management programmes have become more expensive as they shifted from OPs to MD supported by a diversity of supplemental spray programmes using several new insecticides (see Table 9.1). The evolution of resistance to these new insecticides and their negative impacts on $\mathrm{BC}$ continue to be key concerns in implementing sustainable IPM programmes (Brunner et al., 2005).

\section{Epilogue}

Several factors have contributed to the success of the CAMP programme (Coop et al., 1999). These can be grouped into two categories: (i) operational - the availability of several effective and selective tactics for both the key and secondary pests backed by technical support; and (ii) organizational - well-funded, coordinated programmes directly involving growers, researchers, industry leaders and governmental administrators. The lesson learned from the CAMP programme is that pest management is similar to rocket science and requires attention, experience and skill to be effective (Knight, 1999). Dissemination of knowledge and coordination of actions by individual growers have been shown to improve pest management, and offer tremendous benefits to society. Future efforts should focus on how similar, grower-based organizations can be developed and sustained.

\section{References}

Alway, T. (1997) Mating disruption use in Washington State: grower survey report. Areawide IPM Update 2, 1-3.

Alway, T. (1998a) Codling Moth Mating Disruption and Establishing a Pheromone-based Codling Moth Management Site in the Pacific Northwest. Washington State University Cooperative Extension, Wenatchee, Washington.

Alway, T. (1998b) Codling moth mating disruption use in Washington State. Areazide IPM Update 3, 1-2.

Barnes, M.M. (1959) Deciduous fruit insects and their control. Annual Review of Entomology 4, 343-362. 
Barnes, M.M. (1991) Codling moth occurrence, host race formation, and damage. In: van der Geest, L.P.S. and Evenhuis, H.H. (eds) Tortricid Pests: their Biology, Natural Enemies and Control. Elsevier, Amsterdam, pp. 313-327.

Barnes, M.M., Millar, J.G., Kirsch, P.A. and Hawks, D.C. (1992) Codling moth (Lepidoptera: Tortricidae) control by dissemination of synthetic female sex pheromone. Foumal of Economic Entomology 85, 1274-1277.

Barrett, B.A. (1988) The population dynamics of Pnigalio flavipes (Hymenoptera: Eulophidae), the major parasitoid of Phyllonorycter elmaella (Lepidoptera: Gracillariidae) in central Washington apple orchards. PhD dissertation, Washington State University, Pullman, Washington, $173 \mathrm{pp}$.

Beers, E.H., Brunner, J.F., Willett, M.J. and Warner, G.M. (1993) Orchard Pest Management. Good Fruit Grower, Yakima, Washington.

Beers, E.H., Himmel, P.D., Dunley, J.E., Brunner, J.F., Knight, A., Higbee, B., Hilton, R., VanBuskirk, P. and Welter, S. (1998) Secondary pest abundance in different management systems. Washington Horticultural Association Proceedings 94, 121-127.

Bloem, K.A. and Bloem, S. (2000) SIT for codling moth eradication in British Columbia, Canada. In: Tan, K.H. (ed.) Areawide Control of Fruit Flies and Other Insect Pests. Penerbit University Sains Malaysia, Pulau Pinang, Malaysia, pp. 207-214.

Brown, D.F., Knight, A.L., Howell, J.F., Sell, C.R., Krysan, J.L. and Weiss M. (1992) Emission characteristics of a polyethylene pheromone dispenser for mating disruption of codling moth (Lepidoptera: Tortricidae). Foumal of Economic Entomology 85, 910-917.

Brown, E.E. (1953) Life cycle of the lesser apple worm in northeastern Oregon. Foumal of Economic Entomology 46, 1631-1641.

Brunner, J.F. (1992) Leafroller biocontrol: promising new parasites discovered. Washington Horticultural Association Proceedings 88, 285-288.

Brunner, J.F. (1994) Using Bt products as tools in pest control. Good Fruit Grower 45, 34-38.

Brunner, J.F. (1999) New pests: a challenge for areawide programs. Washington Horticultural Association Proceedings 95, 154-158.

Brunner, J.F. and Beers, E.H. (1990) Pandemis and Obliquebanded Leafrollers. Washington State University Extension Bulletin 1582, Washington State University, Pullman, Washington.

Brunner, J.F., Hoyt, S.C. and Wright, M.A. (1982) Codling Moth Control-a Nere Tool for Timing Sprays. Washington State University Extension Bulletin 1072, Pullman, Washington.

Brunner, J., Gut, L. and Knight, A. (1992) Transition of apple and pear orchards to a pheromonebased pest management system. Washington Horticultural Association Proceedings 88, 169-175.

Brunner, J.F., Beers, E., Doerr, M. and Granger, K. (2005) Managing Apple Pests without Organophosphates. Good Fruit Grower, Yakima, Washington.

Brunner, J.F., Dunley, J.E., Beers, E.H. and Jones V.P. (2007) Building a multi-tactic biologically intensive pest management system for Washington orchards. In: Felsot, A.S. and Racke, K.D. (eds) Crop Protection Products for Organic Agriculture: Environment, Health, and Efficacy Assessment. American Chemical Society, Washington DC, pp. 131-143.

Bush, M., Higbee, B., Peterson, B., Simone, N. and Weddle, P. (1999) Pear Insect Field Guide. Good Fruit Grower, Yakima, Washington.

Byers, R.E., Lyons, G.G., Yoder, K.S., Horsburgh, R.L., Barden, J.A. and Donohue, S.J. (1984) Effects of apple tree size and canopy density on spray chemical deposit. Horticultural Science 19, 93-94.

Calkins, C.O. (1998) Review of the codling moth areawide suppression program in the western United States. Journal of Agricultural Entomology 15, 327-333.

Calkins, C. (1999) Codling moth areawide management: a successful 5-year program. Washington Horticultural Association Proceedings 95, 15 l-153.

Calkins, C.O. (2003) Areawide program for suppression of codling moth in the western United States. IOBC wprs Bulletin 26, 21-25. 
Calkins, C.O. and Faust, R.J. (2003) Overview of areawide programs and the program for suppression of codling moth in the western USA directed by the United States Department of Agriculture-Agricultural Research Service. Pest Management Science 59, 601-604.

Calkins, G.O., Knight, A.L., Richardson, G. and Bloem, K.A. (2000) Area-wide population suppression of codling moth. In: Tan, K.H. (ed.) Areawide Control of Fruit Flies and Other Insect Pests. Penerbit University Sains Malaysia, Pulau Pinang, Malaysia, pp. 215-219.

Charmillot, P.J. (1990) Mating disruption technique to control codling moth in western Switzerland. In: Ridgway, R. Silverstein, R.M. and Inscoe, N. (eds) Behavior-modifying Chemicals for Insect Management: Applications of Pheromones and other Attractants. Marcel Dekker, Inc., New York, pp. 165-182.

Connor, J.D. and Higbee, B. (1999) The economics of mating disruption based on pest control in central Washington apples. Washington Horticultural Association Proceedings 95, 161-166.

Coop, L., Kogan, M. and Bajwa, W. (1999) Areawide codling moth: extending the principles and lessons learned outside the project and to other commodities. Washington Horticultural Association Proceedings 95, 176-183.

Croft, B.A. (1979) Management of apple arthropod pests and natural enemies relative to developed resistance. Environmental Entomology 8, 583-586.

Croft, B.A. and Bode, W.M. (1983). Tactics for deciduous fruit IPM. In: Croft, B.A. and Hoyt, S.C. (eds) Integrated Management of Insect Pests of Pome and Stone Fruits. John Wiley and Sons, New York, pp 219-270.

Croft, B.A. and Riedl, H.W. (1991) Chemical control and resistance to pesticides of the codling moth. In: van der Geest, L.P.S. and Evenhuis, H.H. (eds) Tortricid Pests: their Biology, Natural Enemies and Control. Elsevier, Amsterdam, pp. 371-387.

Cutwright, C.R. (1954) A codling moth population resistant to DDT. Joumal of Economic Entomology 47, 189-190.

Dunley, J.E. and Welter, S.C. (2000) Correlated insecticide cross-resistance in azinphosmethylresistant codling moth (Lepidoptera: Tortricidae). Joumal of Economic Entomology 93, 955-962.

Elkins, R.B. (2002) Areazide Implementation of Mating Disruption in Pears Using Puffers. California Department of Pesticide Regulation, Agreement No. 00-0198 S, Sacramento, California.

Elkins, R.B., Klonsky, K.M. and DeMoura, R.L. (2005) Cost of production for transitioning from conventional codling moth control to aerosol-released mating disruption ('puffers') in pears. Acta Horticulturae 671, 559-563.

Falcon, L.A. and Huber, J. (1991) Biological control of the codling moth. In: van der Geest, L.P.S. and Evenhuis, H.H. (eds) Tortricid Pests: their Biology, Natural Enemies and Control. Elsevier, Amsterdam, pp. 355-369.

Ferro, D.N., Sluss, R.R. and Harwood, R.F. (1974) Changes in the population dynamics of the codling moth, Laspeyresia pomonella, after release from insecticide pressures. Environmental Entomology 3, 686-690.

Fritsch, E., Undorf-Spahn, K., Kienzle, J., Zebitz, C.P.W. and Huber, J. (2005) Apfelwicker granulovirus: erst hinweise auf unterschiede in der empfindlichkeit lokaler apfelwickler populationen. Nachrichtenblatt Deutsche Pflanzenschutzdienst 57, 29-34.

Gut, L.J. and Brunner, J.F. (1996) Implementing Codling Moth Mating Disruption in Washington Pome Fruit Orchards. Tree Fruit Research and Extension Center Information Series, No.1, Washington State University, Pullman, Washington.

Gut, L.J. and Brunner, J.F. (1998) Pheromone-based management of codling moth (Lepidoptera: Tortricidae) in Washington apple orchards. Foumal of Agricultural Entomology 15, 387-405.

Gut, L.J., Brunner, J.F. and Knight, A. (1992) Mating disruption as a control for codling moth and leafrollers. Good Fruit Grower 43, 56-60.

Gut, L., Brunner, J.F., and Knight A. (1995) Implementation of pheromone-based pest management programs. Washington Horticultural Association Proceedings 91, 227-234. 
Hansen, J.D. and Johnson, J.A. (2007). Introduction. In: Hansen, J.D. and Johnson, J.A (eds) Heat Treatments for Postharvest Pest Control. CAB International, Wallingford, UK, pp. 1-26.

Higbee, B.S. and Calkins, G.O. (2000) Five year summary of the Parker Heights CAMP project. Proceedings Westem Orchard Pest and Disease Management Conference 74, 15-16.

Higbee, B.S., Galkins, G.O. and Temple, C.A. (2001) Overwintering of codling moth (Lepidoptera: Tortricidae) larvae in apple harvest bins and subsequent moth emergence. Joumal of Economic Entomology 94, 1511-1517.

Hough, W.S. (1928) Relative resistance to arsenical poisoning of two codling moth strains. Joumal of Economic Entomology 22, 325-329.

Howell, J.F. (1991) Reproductive biology. In: van der Geest, L.P.S. and Evenhuis, H.H. (eds) Tortricid Pests: their Biology, Natural Enemies and Ccontrol. Elsevier, Amsterdam, pp. 157-174.

Howell, J.F. and Maitlen, J.C. (1987) Accelerated decay of residual azinphosmethyl and phosmet by sprinkler irrigation above trees and its effect on control of codling moth based on laboratory bioassays as estimated by laboratory simulation of insecticide deposits. Journal of Agricultural Entomology 4, 281-288.

Howell,J. F. and Britt, R. (1994) IPM changes associated with using mating disruption to control codling moth in commercial apple production. Washington Horticultural Association Proceedings 89, 258-264.

Hoyt, S.C. (1969) Integrated chemical control of insects and biological control of mites on apple in Washington. Joumal of Economic Entomology 62, 74-86.

Hoyt, S. (1983) Biology and control of the western tentiform leafminer. Proceedings of the Washington State Horticultural Association 79, 115-1 18.

Ing, G. (1992) Apple 1992. Washington Tree Fruit Research Commission, Wenatchee, Washington.

Ing, G. (1995) Apple Entomological Research Review. Washington State Tree Fruit Research commission, Wenatchee, Washington.

Ing, G. (1999) Almost thirty years of grower codling moth research funding. Washington Horticultural Association Proceedings 95, 184.

Jackson, D.M. (1979) Codling moth egg distribution on unmanaged apple trees. Annals of the Entomological Society of America 72, 361-368.

Jang, E.B. and Moffitt, H.R. (1994) Systems approaches to achieving quarantine security. In: Sharp, J.L. and Hallman, G.J. (eds) Quarantine Treatments for Pests of Food Plants. Oxford \& IBH Publishing Co., New Delhi, India, pp. 225-237.

Judd, G.J.R., Gardiner, M.G.T. and Thomson, D.R. (1997) Control of codling moth in organically managed apple orchards by combining pheromone-mediated mating disruption, post-harvest fruit removal and tree banding. Entomologia Experimentalis et Applicata 83, $137-146$.

Knight, A. (1992) New dimensions in mating disruption of codling moth. Washington Horticultural Association Proceedings 88, 166-168.

Knight, A. (1994) Insect pest and natural enemy populations in paired organic and conventional apple orchards in the Yakima Valley, Washington. Fournal of the Entomological Society of British Columbia 91, 27-36.

Knight, A. (1995a) The impact of codling moth (Lepidoptera: Tortricidae) mating disruption on apple pest management in Yakima Valley, Washington. Joumal of the Entomological Society of British Columbia 92, 29-38.

Knight, A.L. (1995b) Evaluating pheromone emission rate and blend in disrupting sexual communication of codling moth (Lepidoptera: Tortricidae). Environmental Entomology 24, 1396-1403.

Knight, A.L. (1996) Sexual biology and mating disruption of orange tortrix, Argyrotaenia citrana (Lepidoptera: Tortricidae). Joumal of the Entomological Society of British Columbia 93, 111-120.

Knight, A. (1997) Optimizing the use of Bts for leafroller control. Good Fruit Grower 48, 47-49. 
Myburgh, A.C. (1980) Infestation potential of the codling moth. Deciduous Fruit Grower 10, 368-377.

Newcomber, E.J. (1936) Orchard sanitation for control of codling moth. Washington State Horticultural Association Proceedings 31, 140-141.

Prokopy, R.J. and Croft, B.A. (1994) Apple insect pest management. In: Metcalf, R.L. and Luckmann, W.H. (eds) Introduction to Pest Management. John Wiley and Sons, Inc., New York, pp. 543-585.

Proverbs, M.D. and Newton, J.R. (1975) Codling moth control by sterile insect release: importation of fruit and fruit containers as a source of reinfestation. Journal of the Entomological Society of British Columbia 72, 6-9.

Reyes, M., Franck, P., Charmillot, P.J.,Ioratti, C., Olivares, J., Pasqualini, E. and Sauphanor, B. (2008) Diversity of insecticide resistance mechanisms in European populations of the codling moth, Cydia pomonella. Pesticide Science (In press).

Riedl, H. and Croft, B.A. (1978) The effects of photoperiod and effective temperatures on the seasonal phenology of the codling moth (Lepidoptera: Tortricidae). The Canadian Entomologist $110,455-470$.

Riedl, H., Howell, J.F., McNally, P.S. and Westigard, P.H.. (1986) Codling Moth Management: Use and Standardization of Pheromone Trapping Systems. University of California Division of Agriculture and Natural Resources, Bulletin 1918, Oakland, California.

Sauphanor, B. and Bouvier, J.C. (1995) Cross-resistance between benzoylureas and benzoylhydrazines in the codling moth, Cydia pomonella L. Pesticide Science 45, 369-375.

Shel'deshova, G.G. (1967) Ecological factors determining the distribution of the codling moth, Laspeyresia pomonella L. (Lepidoptera: Tortricidae) in the northern and southern hemispheres. Entomological Review 46, 349-361.

Shorey, H.H. and Gerber, R.G. (1996) Use of puffers for disruption of sex pheromone communication of codling moths (Lepidoptera: Tortricidae) in walnut orchards. Environmental Entomology 25, 1398-1400.

Smirle, M.J., Vincent, C., Zurowski, C.L. and Rancourt, B. (1998) Azinphosmethyl resistance in the obliquebdnaded leafroller, Choristoneura rosaceana: reversion in the absence of selection and relationship to detoxification enzyme activity. Pesticide Biochemistry Physiology 61, $183-189$.

Travis, J.W. and Rajotte, E.G. (1995) Implementing IPM through new technologies and the non-agricultural community. Foumal of Agricultural Entomology 12, 219-227.

Trimble, R.M. (1995) Mating disruption for controlling the codling moth, Cydia pomonella (L.) (Lepidoptera: Tortricidae) in organic apple production in southwestern Ontario. The Canadian Entomologist 127, 493-505.

VanBuskirk, P., Hilton, R., Simone, N. and Alway, T. (1998) Orchard Pest Monitoring Guide for Pear: a Resource Book for the Pacific Northwest. Good Fruit Grower, Yakima, Washington.

VanBuskirk, P., Hilton, R., Westigard, P. and Naumes, L. (1999) Orchard monitoring - the foundation of an areawide program. Washington Horticultural Association Proceedings 95, 159-160.

Van de Baan, H.E. and Croft, B.A. (1991) Resistance to insecticides in winter and summer form of Psylla pyricola. Pesticide Science 32, 225-233.

Varela, L.G., Welter, S.C., Jones, V.P., Brunner, J.F. and Riedl, H. (1993) Monitoring and characterization of insecticide resistance in codling moth (Lepidoptera: Tortricidae) in four western states. Foumal of Economic Entomology 86, 1-10.

Weddle, P.W. (1993) Barriers to the Implementation of Mating Dismution for Control of Codling Moth. Weddle, Hansen \& Associates, Placerville, California.

Weddle, P.W. (1994) Management of Codling Moth in Bartlett Pears in Califomia: a Preliminary analysis of the Relative Costs of Insecticide- and Pheromone-based IPM Strategies. Weddle, Hansen \& Associates, Placerville, California. 
Weissling, T.J. and Knight, A.L. (1995) Vertical distribution of codling moth adults in pheromone-treated and untreated plots. Entomologia Experimentalis et Applicata 77, 271-275.

White, L.D., Hutt, R.B. and Butt, B.A. (1973) Field dispersal of laboratory-reared fertile female codling moth and population suppression by release of sterile males. Environmental Entomology 2, 66-69.

Willett, M. (2006) The 1996 Food Quality Protection Act after a decade. Washington Horticultural Association Proceedings 103, 162-165.

Williams, K.M. (1993) Use of evaporative cooling for enhancing apple fruit quality. Washington Horticultural Association Proceedings 89, 97-99.

Willamson, E.R., Folwell, R.J., Knight, A. and Howell, J.F. (1996) Economics of employing pheromones for mating disruption of the codling moth, Carpocapsa pomonella. Crop Protection $15,473-477$. 